\title{
Antifertility effect of curcumin, an indigenous medicine in rats
}

\author{
R. N. Maiti ${ }^{1 *}$, U. K. Roy ${ }^{2}$, Subhayan Das ${ }^{1 *}$, A. K. $\operatorname{Das}^{3}$
}

${ }^{1}$ Department of Pharmacology, Midnapore Medical College, Midnapore, West Bengal, India
${ }^{2}$ Department of Anaesthesiology, Murshidabad Medical College, Midnapore, West Bengal, India
${ }^{3}$ Department of Pharmacology, R. G. Kar Medical College, West Bengal, India

Received: 16 November 2020

Revised: 19 December 2020

Accepted: 29 December 2020

\section{*Correspondence:}

Dr. Subhayan Das,

Email: drsubhayandas198@gmail.com

Copyright: (C) the author(s), publisher and licensee Medip Academy. This is an open-access article distributed under the terms of the Creative Commons Attribution Non-Commercial License, which permits unrestricted non-commercial use, distribution, and reproduction in any medium, provided the original work is properly cited.

\begin{abstract}
Background: Curcumin is an active constituent, obtained from rhizome of Curcuma longa linn, known to have broad medicinal properties, was studied for its effect on fertility in female rats. Curcumin has anti-ovulatory effect probably by its antiestrogenic activity through suppression of negative feedback of estrogen on pituitary.

Methods: Inbred Charles Foster female albino rats (150-180 gm) were used for study. They were divided into different groups and treated with curcumin $(25 \mathrm{mg} / \mathrm{kg}$. and $50 \mathrm{mg} / \mathrm{kg}$ body weight $)$ as per schedule. The antigonadotropic, antiestrogenic, anti-implantation and abortifacient effect on curcumin treated albino rats were demonstrated.

Results: The results showed significant reduction in the number of implants and size of litters in curcumin treated rats compared to normal control group. The results were compared with Tamoxifen (10mg/ kg bodyweight) a known antifertility drug, which further substantiated the antifertility effects of curcumin.

Conclusions: The results indicated the ways in which curcumin exerts antifertility effects and thus can play a vital role in fertility control.
\end{abstract}

Keywords: Curcuma longa linn, Antifertility effect, Indigenous medicine

\section{INTRODUCTION}

Ancient Indian literature carries information about a large number of plants reported to have abortifacient, antiseptic and contraceptive properties, and have been used by various rural communities to prevent contraception and for other benefits. Adequate control of birth rate figures has remained the main basis of the various population control and family welfare measures in India. ${ }^{1}$ Curcumin, is an Indian ayurvedic preparation, obtained from rhizome of Curcuma longa linn. It is a non-steroidal compound and has been reported to possess some contraceptive activity. ${ }^{2}$ The rhizome of the plant, turmeric from which the active principle curcumin is obtained, is consumed almost daily as a flavouring agent by the people of India. ${ }^{3}$ It is nontoxic and has been reported earlier to have reversible anti-ovulatory, and antiimplantation effects. ${ }^{4,5}$ The present work has been undertaken to study the effects of curcumin on different variables of fertilization to establish its antifertility activity as well as to elucidate its probable mechanism of action. The difference in weight between ovaries prior to and after treatment with drugs was recorded.

\section{METHODS}

Curcumin dissolved in propylene glycol was used in the present study. Inbred Charles-Foster albino rats of different weight used in the present study were obtained from the central animal house of the institute. The 
experiment is performed in animal house facility and departmental laboratory of Midnapore medical college and hospital (January 2020 to March 2020). They were housed in colony cages in the department's temperaturecontrolled animal room $\left(26^{\circ} \mathrm{C} \pm 3^{\circ} \mathrm{C}\right)$ with $10: 14$ hour, L: $\mathrm{D}$ cycle for at least 2 weeks before and during the experiment. They are fed on laboratory diet and water was allowed ad libitum. The experiments were carried out on the following parameters; antigonadotropic effect, antiestrogenic effect, antiimplantation effect and abortifacient effect.

\section{Anti-gonadotropic effect}

Effect of the drug in unilateral ovariectonised albino rats: 24 female albino rats weighing between 150-180 gm were studied for five normal oestrous cycles by vaginal smear method. The dry weight of each ovary was noted in all animals after left sided ovariectomy under ether anaesthesia. ${ }^{6}$ The animals were then divided into four groups of six animals each. The control group received no treatment; second and third group received curcumin in doses of $25 \mathrm{mg} / \mathrm{kg}$ and $50 \mathrm{mg} / \mathrm{kg}$ respectively; while fourth group received tamoxifen $10 \mathrm{mg} / \mathrm{kg}$ body weight for 10 days. On $11^{\text {th }}$ day, the other ovary from each animal was dissected out and dry weight was noted individually. The difference between pre- and posttreatment of ovaries were recorded. Effect of Pituitary extract of untreated and curcumin treated male rats on genital organs of curcumin treated and untreated female albino rats: Male albino rats weighing between 150-180 gm were sacrificed to obtain pituitary extract in the study. ${ }^{7} 18$ female albino rats weighing between $50-55 \mathrm{gm}$ were included in 3 groups of 6 animals each in the study. The 1 st receiving no treatment served as control while $2^{\text {nd }}$ group received p-glycol orally $(2.5 \mathrm{ml} / \mathrm{kg})$ and $3^{\text {rd }}$ group received curcumin $(50 \mathrm{mg} / \mathrm{kg}$ body weight) orally for 4 days. From the $2^{\text {nd }}$ day of curcumin treatment, pituitary extract were administered to all groups in a dose of $0.2 \mathrm{ml}$ twice daily intraperitoneally for 3 days. On $5^{\text {th }}$ day, all animals were sacrificed to obtain uteri and ovaries and dry weights were recorded individually. Effect of pituitary extract of curcumin treated male rats on untreated immature female rats; 20 male albino rats of 10 animals each in 2 groups were treated with p-glycol $(2.5$ $\mathrm{ml} / \mathrm{kg}$ body weight) and curcumin $(50 \mathrm{mg} / \mathrm{kg}$ body weight) orally for 10 days respectively. On $11^{\text {th }}$ day, animals are sacrificed to obtain pituitaries and extracts were prepared. 12 females rats of 50-55 gm in two groups of 6 animals each were treated with pituitary extract $(0.2$ $\mathrm{ml} \mathrm{BD} \times 3$ days, intra peritoneal) on the $5^{\text {th }}$ day, all animals were sacrificed and dry weight of uteri and ovaries were noted individually. The control animals of previous experiments also served as control in this study.

\section{Anti-oestrogenic effect}

Effect of oestrogen on uterine weight of curcumin and tamoxifen pre-treated female albino rats: 30 female albino rats weighing between 80 to 100 gms in 5 groups of 6 animals each were studied. ${ }^{8}$
Group I was taken as control, group II received standard oestrogen ( $0.1 \mu \mathrm{g}$ subcutaneously od for 3 days), group III received curcumin $(25 \mathrm{mg} / \mathrm{kg})$ and standard oestrogen $(0.1 \mu \mathrm{g}$ subcutaneously od $\times 3$ days), group IV received curcumin $(50 \mathrm{mg} / \mathrm{kg})$ and standard oestrogen $(0.1 \mu \mathrm{g}$ subcutaneously od $\times 3$ days) and group $\mathrm{V}$ received tamoxifen $(10 \mathrm{mg} / \mathrm{kg})$ and standard oestrogen $(.1 \mu \mathrm{g}$ subcutaneously od $\times 3$ days).

On $4^{\text {th }}$ day, uteri of all animals were dissected out by laparotomy under ether anaesthesia and weighed individually. Effect of cucurmin on urinary oestriol level of female virgin and pregnant rats: Urinary oestriol from 24 hours urine of both virgin and pregnant albino rats were measured to see the possible anti-estrogenic effect of the drug. ${ }^{9} 12$ female virgin albino rats in groups of 6 animals each were included in the study. Group I receiving no treatment served as control. While group II received curcumin ( $50 \mathrm{mg} / \mathrm{kg}$ body weight $\times 3$ days). Another 30 fertile female albino rats were mated with male rats in 1:1 ratio in individual cages. Appearance of spermatozoa in vaginal smear was taken as day 1 of pregnancy.

The pregnant rats were then divided into 2 groups of 6 animals each. Group I served as control receiving no treatments, group II received curcumin $(50 \mathrm{mg} / \mathrm{kg})$ for 3 days from day 7-9 of pregnancy. All the female rats were kept individually in separate glass metabolite cages on $4^{\text {th }}$ day of drug treatment. Before placing in metabolic cage, they were given a water load of $5 \mathrm{ml} / \mathrm{kg}$. The volume of urine excreted by each rat in 24 hours was collected individually group wise.

\section{Anti-implantation effect}

Eighteen fertile female albino rats weighing between 175-225 gm was allowed to mate in 1:1 ratio with male rats in separate cages. Vaginal appearance of spermatozoa in smear was taken as day 1 of pregnancy in particular animal. Then the female rats were isolated in separate cages and divided into 3 groups of 6 animals each. Group I served as control, while group II and group III received curcumin in doses of $50 \mathrm{mg} / \mathrm{kg}$ and 100 $\mathrm{mg} / \mathrm{kg}$ orally respectively from day 1 to day 7 . All the female rats were weighed daily till term. The number of litters delivered by each animal at term and their viability were recorded.

\section{Abortifaecient effect}

Sixty female fertile rats were mated with male rats and pregnant rats were isolated as before. They were divided into groups of 6 animals each. Curcumin in doses of 50 $\mathrm{mg} / \mathrm{kg}$ and $100 \mathrm{mg} / \mathrm{kg}$ were administered orally from day $1-9,10-12,12-14$ of pregnancy in respective groups. Control animals received only p-glycol orally for similar duration. The total numbers of litters delivered and their viability were recorded as before. 


\section{Statistical analysis}

Statistical analysis was performed using SPSS version 21. Data was entered on Microsoft Excel and continuous variables were summarized as mean and standard deviation.

\section{RESULTS}

\section{Antigonadotropic effect}

Effects on ovarian weight of unilateral ovariectomised rats are depicted in (Table 1 and Figure1). Results showed an increase in weight of remaining ovary to 181.4 percent in control animals, while it was only 33.8 percent and 16.3 percent with curcumin treatment in doses 25 $\mathrm{mg} / \mathrm{kg}$ and $50 \mathrm{mg} / \mathrm{kg}$. Again it was only 7.3 percent in tamoxifen treated group, indicating a dose-dependent reduction in ovarian weight by curcumin similar to tamoxifen, results were reported as mean \pm SEM. Effect of
Results of pituitary extract from untreated male rats on ovarian and uterine weight in curcumin treated immature female rats are shown in (Table 2). Injection of pituitary extract from untreated male rats in animals resulted an increase in ovarian and uterine weight by 148.5 and 143 percent respectively compared to untreated control group. Results of effect of pituitary extract from curcumin treated male rats on ovarian and uterine weight of untreated immature female rats are depicted in (Table 3). While pituitary extract from untreated male rats caused a significant increase in ovarian and uterine weight in untreated control rats by 148.7 and 143 percent respectively, administration of pituitary extract obtained from curcumin treated male rats caused a increase in ovarian and uterine weight in female rats by 158.7 and 155.1 percent respectively, showing no significant difference in increase of ovarian and uterine weight from pituitary extract treated control group.

Table 1: Effects of curcumin and tamoxifen on ovarian weight in unilateral ovariectomised albino rats.

\begin{tabular}{|lllll|}
\hline $\begin{array}{l}\text { Group } \\
\text { (N=6) }\end{array}$ & Treatment, & $\begin{array}{l}\text { Weight of the control } \\
(\mathbf{m g})(\text { Mean+SEM) }\end{array}$ & $\begin{array}{l}\text { Weight of the ovary after } \\
\text { drug }(\mathbf{m g})(\text { Mean+SEM) }\end{array}$ & \% increase \\
\hline I & Control & $30.50 \pm 2.03$ & $85.88 \pm 2.38$ & 181.4 \\
\hline II & Curcumin $(25 \mathrm{mg} / \mathrm{kg})$ & $30.00 \pm 2.04$ & $40.16 \pm 1.56$ & 33.8 \\
\hline III & Curcumin $(50 \mathrm{mg} / \mathrm{kg})$ & $30.23 \pm 2.01$ & $35.16 \pm 2.07$ & 16.3 \\
\hline IV & Tamoxifen $(10 \mathrm{mg} / \mathrm{kg})$ & $30.85 \pm 2.05$ & $33.12 \pm 1.78$ & 7.3 \\
\hline
\end{tabular}

Table 2: Effects of pituitary extract from untreated male rats on ovarian and uterine weight on curcumin treated immature female rats.

\begin{tabular}{|llllllcc|}
\hline $\begin{array}{l}\text { Group } \\
(\mathbf{N}=6)\end{array}$ & Drug treatment & $\begin{array}{l}\text { Weight of } \\
\text { ovary }(\mathbf{m g})\end{array}$ & $\begin{array}{l}\text { Weight of } \\
\text { uterus }(\mathbf{m g})\end{array}$ & $\begin{array}{l}\text { Gain in } \\
\text { weight }(\mathbf{m g}) \\
\text { of ovary }\end{array}$ & $\begin{array}{l}\text { Gain in } \\
\text { weight of } \\
\text { uterus }(\mathbf{m g})\end{array}$ & $\begin{array}{l}\text { \% increase } \\
\text { in weight of } \\
\text { ovary }\end{array}$ & $\begin{array}{l}\% \text { increase } \\
\text { in weight } \\
\text { of uterus }\end{array}$ \\
\hline I & Control & $12.21 \pm 0.78$ & $49.5 \pm 1.12$ & - & - & - & - \\
\hline II & Pituitary extract & $30.35 \pm 1.10$ & $120.3 \pm 1.83$ & $18.14 \pm 1.02$ & $70.8 \pm 1.72$ & 148.5 & 143.0 \\
\hline III & $\begin{array}{l}\text { Pituitary extract } \pm \\
\text { curcumin }\end{array}$ & $15.25 \pm 0.87$ & $54.2 \pm 1.32$ & $3.04 \pm 0.72$ & $4.7 \pm 0.82$ & 24.8 & 9.4 \\
\hline
\end{tabular}

Table 3: Effect of pituitary extract from curcumin treated male rats on ovarian and uterine weight of untreated immature female rats $(\mathbf{p}>\mathbf{0 . 0 5})$.

\begin{tabular}{|llllllll|}
$\begin{array}{l}\text { Group } \\
(\mathbf{N}=\mathbf{6})\end{array}$ & Drug treatment & $\begin{array}{l}\text { Weight of } \\
\text { ovary }(\mathbf{m g})\end{array}$ & $\begin{array}{l}\text { Weight of } \\
\text { uterus }(\mathbf{m g})\end{array}$ & $\begin{array}{l}\text { Gain in } \\
\text { weight of } \\
\text { ovary }(\mathbf{m g})\end{array}$ & $\begin{array}{l}\text { Gain in } \\
\text { weight of } \\
\text { uterus }(\mathbf{m g})\end{array}$ & $\begin{array}{l}\text { \% increase } \\
\text { in weight of } \\
\text { ovary }\end{array}$ & $\begin{array}{l}\text { \% increase } \\
\text { in weight of } \\
\text { uterus }\end{array}$ \\
\hline I & Control & $12.21 \pm 0.78$ & $47.5 \pm 1.12$ & - & - & - & - \\
\hline II & Pituitary extract & $30.35 \pm 1.10$ & $120.2 \pm 1.83$ & $18.15 \pm 1.23$ & $70.8 \pm 1.78$ & 148.7 & 143.0 \\
\hline III & Curcumin & $31.57 \pm 1.52$ & $126.3 \pm 2.01$ & $19.37 \pm 1.67$ & $76.8 \pm 2.12$ & 158.7 & 155.1 \\
\hline
\end{tabular}

\section{Anti-oestrogenic effect}

Results of effect of oestrogen on uterine weight in curcumin and tamoxifen in pretreated female rats are depicted in (Table 4). While only oestrogen treatment caused an increase in uterine weight from $128.4 \mathrm{mg}$ to $304.3 \mathrm{mg}$ i.e. 36 percent increase in weight in control group, in curcumin pretreated rats in doses of $25 \mathrm{mg} / \mathrm{kg}$ and $50 \mathrm{mg} / \mathrm{kg}$ body weight, these increase were $175.2 \mathrm{mg}$ and $152.3 \mathrm{mg}$ respectively, indicating a dose dependent gain in weight.

In tamoxifen pre-treated group this gain in weight was $12.9 \mathrm{mg}$ only compared to $175.9 \mathrm{mg}$ with oestrogen only. Results thus showed a reduction in uterine weight by both curcumin and tamoxifen in same way. 
Table 4: Effect of oestrogen on uterine weight in curcumin and tamoxifen pretreated female rats $(\mathbf{p}<0.05)$.

\begin{tabular}{|lllcc|}
$\begin{array}{l}\text { Group } \\
(\mathbf{N}=6)\end{array}$ & Drug treatment & Uterine weight $(\mathrm{mg})$ & $\begin{array}{l}\text { Gain in uterine } \\
\text { weight }(\mathbf{m g})\end{array}$ & \% increase in weight \\
\hline I & Control & $128.4 \pm 5.32$ & - & - \\
\hline II & Oestrogen & $304.3 \pm 7.42$ & $175.9 \pm 5.27$ & 136.9 \\
\hline III & Oestrogen+curcumin $(25 \mathrm{mg} / \mathrm{kg})$ & $175.2 \pm 6.25$ & $46.8 \pm 4.37$ & 36.4 \\
\hline IV & Oestrogen+curcumin $(50 \mathrm{mg} / \mathrm{kg})$ & $152.3 \pm 5.52$ & $23.9 \pm 4.32$ & 18.6 \\
\hline V & Oestrogen+tamoxifen $(10 \mathrm{mg} / \mathrm{kg})$ & $141.3 \pm 4.23$ & $12.9 \pm 4.25$ & 10.0 \\
\hline
\end{tabular}

Table 5: Effect of curcumin on urinary oestriol level of virgin and pregnant albino rats $(\mathbf{p}<0.01)$.

\begin{tabular}{|llllcc|}
\hline $\begin{array}{l}\text { Group } \\
\text { (N=6) }\end{array}$ & Treatment & $\begin{array}{l}\text { Urinary oestriol level } \\
\text { in virgin albino rats }\end{array}$ & $\begin{array}{l}\text { Urinary oestriol level in } \\
\text { pregnant albino rats }\end{array}$ & $\begin{array}{l}\text { \% increase in } \\
\text { weight of virgin } \\
\text { rats }\end{array}$ & $\begin{array}{l}\text { \% increase of } \\
\text { weight of } \\
\text { pregnant rats }\end{array}$ \\
\hline I & Control & $176.2 \pm 18.34$ & $225.4 \pm 18.20$ & - & - \\
\hline II & Curcumin & $111.3 \pm 14.52$ & $147.5 \pm 12.30$ & 36.8 & 34.5 \\
\hline
\end{tabular}

Results of effect of curcumin on urinary oestriol level of female virgin and pregnant rats are depicted in (Table 5). Urinary oestriol level in curcumin treated virgin rats was $111.3 \pm 14.52$ compared to $176.2 \pm 18.34 \mathrm{mg} / \mathrm{ml}$ in control virgin rats, showing a reduction by 36.8 percent in treated group. The urinary oestriol in control pregnant rats was raised to $225.4 \pm 18.32 \mathrm{mg} / \mathrm{ml}$ compared to $176.2 \pm 18.34$ $\mathrm{mg} / \mathrm{ml}$ in virgin control rats. Whereas urinary oestriol level in curcumin treated rats was $147.5 \pm 12.3 \mathrm{mg} / \mathrm{ml}$, which was significantly less to both untreated pregnant as well as to virgin animals.

\section{Anti-implantation effect}

The results showed that number of delivered and viable litters were $2.1 \pm 0.5$ and $1.7 \pm 0.27$ respectively with 50 $\mathrm{mg} / \mathrm{kg}$ and $1.8 \pm 0.7$ and $1.2 \pm 0.4$ respectively with 100 $\mathrm{mg} / \mathrm{kg}$ of curcumin treated animals, which were significantly less in untreated animals, where observations were $7.2 \pm 0.5$ and $6.5 \pm 0.3$ respectively (Table 6).

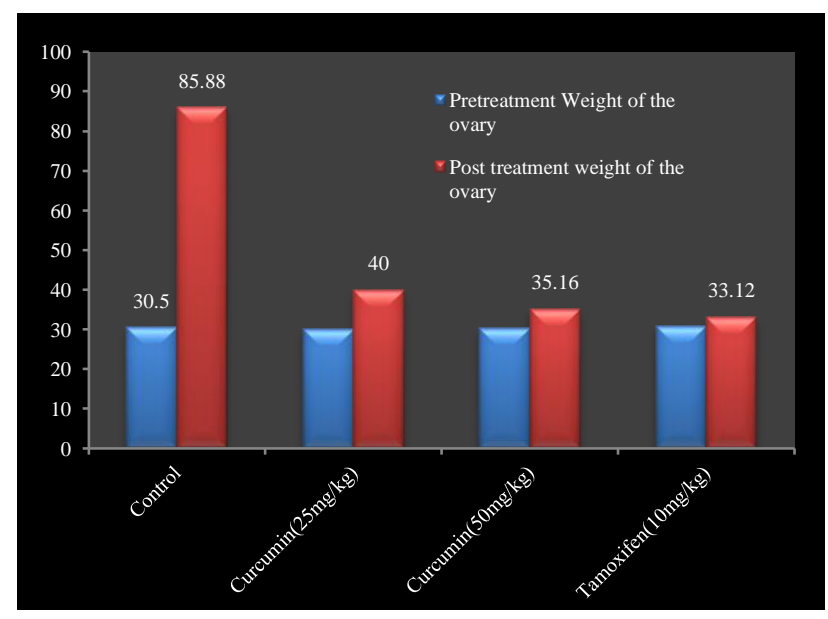

Figure 1: Effects of curcumin and tamoxifen on ovarian weight in unilateral ovariectomised albino rats $(\mathrm{N}=6)$.

\section{Abortifacient effect}

In the control group, the number of litters delivered were $7.6 \pm 1.12$, of which $7.2 \pm 1.1$ were viable. Curcumin in the dose of $50 \mathrm{mg} / \mathrm{kg}$ administered between day 7-9, 10-12 and 12-14 of pregnancy reduced the number of litters delivered and viable litters as follows: $4.6 \pm 1.1$ and $3.4 \pm 1.2,3.9 \pm 1.1$ and $2.0 \pm 1.2,2.8 \pm 1.1$ and $1.0 \pm 0.3$ respectively, showing 39.4, 48.6 and 52.5 percent reduction in; hypertrophy of ovaries and uterus in a dose dependent manner, similar to tamoxifen, supporting its antigonadotropic effect (Table 7). This effect due to direct antagonism of gonadotrophin or by inhibition of gonadotrophin mediated oestrogen action on the effector cells. The present study also shows antiestrogenic effect of curcumin by reducing uterine hypertrophy induced by member of litters delivered compared to control group. Whereas curcumin in $100 \mathrm{mg} / \mathrm{kg}$ dose, the number of delivered and viable litters were $3.4 \pm 1.3$ and $1.8 \pm 1.10$, $2.9 \pm 1.0$ and $1.8 \pm 0.5,1.9 \pm 1.2$ and $1.0 \pm 0.5$ respectively, showing thereby $55.2,61.8$ and 61.8 percent reduction in number of litters delivered compared to control.

\section{DISCUSSION}

Amtifertility effects of curcumin have been studied against models of fertility parameters. Effects of curcumin have also been compared with tamoxifen, a non steroidal, anti oestrogenic drug in this study, for a structural similarity of both the compounds. Results of the present study show that curcumin reduced exogenous oestrogen and in reducing urinary oestriol level in virgin and pregnant rats. Again this effect is similar to Tamoxifen and possibly due to direct effect of curcumin in inhibiting oestrogen receptors and by indirect mechanism by lowering utilization of cholesterol in synthesis of oestrogen. ${ }^{9-11}$ Curcumin in the present study shows anti-implantation and abortifacient effects by decrease gain in weight, reduction in the number of viable litters. 
Table 6: Effect of curcumin on implantation in rats $(\mathbf{p}<0.05)$.

\begin{tabular}{|llll|}
\hline $\begin{array}{l}\text { Group } \\
(\mathbf{N}=6)\end{array}$ & Treatment & $\begin{array}{l}\text { No. of } \\
\text { litters } \\
\text { delivered at } \\
\text { term }\end{array}$ & $\begin{array}{l}\text { No. of } \\
\text { viable } \\
\text { litters after } \\
\text { birth }\end{array}$ \\
\hline I & Control & $7.2 \pm 0.5$ & $6.5 \pm 0.3$ \\
\hline II & $\begin{array}{l}\text { Curcumin } \\
(50 \mathrm{mg} / \mathrm{kg})\end{array}$ & $2.1 \pm 0.4$ & $1.7 \pm 0.2$ \\
\hline III & $\begin{array}{l}\text { Curcumin } \\
(100 \mathrm{mg} / \mathrm{kg})\end{array}$ & $1.8 \pm 0.7$ & $1.2 \pm 0.4$ \\
\hline
\end{tabular}

These effects are due to altered nuclear processing as well as by lowering progesterone synthesis similar to tamoxifen.

Considering short duration of study period as a study limitation, curcumin, in the present study, produced antigonadotrophic, anti-oestrogenic, anti-implantation and abortifacient effects in a more or less similar fashion as tamoxifen. More over curcumin has a close structural similarity with tamoxifen. Therefore, it may be presumed that mechanism of antifertility effects of curcumin is same as tamoxifen.

Table 7: Abortifacient effect of curcumin administered during 7-9, 9-12 and 12-14 of pregnancy in albino rats.

\begin{tabular}{|llllll|}
$\begin{array}{l}\text { Group } \\
(\mathbf{N}=6)\end{array}$ & Treatment & $\begin{array}{l}\text { Period of } \\
\text { treatment (days) }\end{array}$ & $\begin{array}{l}\text { No. of litters } \\
\text { delivered at terms }\end{array}$ & $\begin{array}{l}\text { No. of viable } \\
\text { litters after birth }\end{array}$ & \% reduction \\
\hline I & Control & - & $7.6 \pm 1.2$ & $7.2 \pm 1.1$ & 39.4 \\
\hline \multirow{3}{*}{ II } & \multirow{3}{*}{ Curcumin $(50 \mathrm{mg} / \mathrm{kg})$} & $7-9$ & $4.6 \pm 1.1$ & $3.4 \pm 1.2$ & 48.6 \\
& & $10-12$ & $3.9 \pm 1.1$ & $2.0 \pm 1.2$ & 52.5 \\
\hline \multirow{3}{*}{ III } & \multirow{2}{*}{ Curcumin $(100 \mathrm{mg} / \mathrm{kg})$} & $12-14$ & $2.8 \pm 1.1$ & $1.0 \pm 0.3$ & 55.2 \\
& & $10-12$ & $3.4 \pm 1.3$ & $1.8 \pm 1.0$ & 61.8 \\
\hline
\end{tabular}

\section{CONCLUSION}

Traditional medicines like curcumin may be used as a potential antifertility agent, thereby replacing the hormonal contraceptives in birth control measures. Extensive in vivo as well as clinical studies are required to substantiate its outcome further.

Funding: No funding sources

Conflict of interest: None declared

Ethical approval: The study was approved by the Institutional Ethics Committee

\section{REFERENCES}

1. Ghosh AK, Das AK, Patra KK. Studies on antifertility effect of rhizome of Curcuma longa linn. Asian J Pharm Life Sci. 2011;1(4):349-53.

2. Kirtikar KR, Basu BD. Indian medical plants. Allahabad: Lalit Mohan publication; 1935.

3. Eigner D, Schlolz D. Ferula asa-foetida and Curcuma longa in traditional medicinal treatment and diet in Nepal. J Ethnopharmacol. 1999;67:1-6.

4. Dasgupta SR, Sinha M, Sahana CC, Mukherjee BP. A study of the effect of an extract of Curcuma longa Linn on experimental gastric ulcers in animals. Indian J Pharmacol. 1969;1(3):49-54.
5. Garg SK, Garg GP. Antifertility screening of plants, effect on pregnancy in albine rats. Indian J Med Res. 1971;59:302-6.

6. Fox BW, Jackson H, Laurence DR, Bacharalh AC. Evaluation of drug activities. London: Academic Press; 1964:2;801

7. Garg SK, Mathur VS, Chaudhury RR. Screening of Indian plants for antifertility activity. Indian J Exp Biol. 1978;16(10):1077-9.

8. Laurence KA. Clinical chemistry, theory analysis and correlation. United States of America: CN Mosby Company; 1984:1145.

9. Garg SK, Mathur VS, Chaudhury RR. Screening of Indian plants for antifertility activity. Planta Med. 1978;26(3):225-7.

10. Atal CK. Chemistry and pharmacology of vasicine, a new oxytocic and abortifacient.Jammu Tawi: Regional Research Laboratory publishers; 1970:6879.

11. Jordan VC, Dix C. Effect of oestradiol benzoate, tamoxifen andmonohydroxytamoxifen on immature rat uterine progesterone receptor synthesis and endometrial cell division. J Steriod Biochem. 1979;11:285-91.

Cite this article as: Maiti RN, Roy UK, Das S, Das AK. Antifertility effect of curcumin, an indigenous medicine in rats. Int $\mathrm{J}$ Basic Clin Pharmacol 2021;10:167-71. 